\title{
Politike simbola na gradskim ulicama: obrasci preimenovanja javnih prostora u postjugoslovenskim zemljama
}

\author{
SRĐAN RADOVIĆ \\ Etnografski institut SANU, Beograd
}

\begin{abstract}
Istraživanje (pre)imenovanja ulica i trgova kao političko-identitetskih simboličkih praksi otpočelo je u hrvatskoj i drugim etnologijama/antropologijama u regiji najkasnije devedesetih godina 20. veka, a omogućeno je i tzv. prostornim obratom u društvenim i humanističkim disciplinama. Interes za ovakve politike javnog prostora proizašao je iz iskustva masovnih preimenovanja ulica, trgova, naselja, pa i čitavih gradova, od 1990. godine naovamo, koja su uzrokovana potpunom transformacijom političko-ekonomske ("tranzicija" iz socijalizma u kapitalizam) i nacionalne paradigme (raspad Jugoslavije i uspostavljanje nezavisnih država). Kao jedan od vidova novih politika identiteta i pamćenja, ulično "uprostoravanje" ideologije intenzivno je provođeno (a što je bio slučaj i u prethodnim epohama), uz određene sličnosti, ali i dosta razlika u odnosu na druge bivše socijalističke zemlje u Evropi. Imajući u vidu sadržinu i opseg recentnih intervencija u simbolički javni prostor, mogla bi se izdvojiti tri preovlađujuća obrasca (pre)imenovanja ulica u postjugoslovenskim zemljama, koja su bila karakteristična za pojedine države i periode (uz neminovne iznimke): parcijalna korekcija pamćenja na socijalizam i modifikacija nacionalnih narativa, opsežno brisanje prostornih markera nedavne prošlosti i suštinska prerada nacionalnih imaginarija, te potpuni prekid sa prostornim simbolizmom prethodne epohe uzrokovan prvenstveno etnopolitičkim ciljevima. Ovi obrasci implementirani su u različitim periodima, te, iako se čine vrlo aktuelnima i tipičnima za ovdašnji prostor, ipak predstavljaju prostorno-političke prakse koje su bile prisutne i u ranijim periodima i u drugim evropskim zemljama.
\end{abstract}

Ključne riječi: odonimi/hodonimi, politike prostora, politike identiteta, kolektivno pamćenje, "postsocijalistički" period

\section{OPROSTORNJAVANJE ANTROPOLOŠKOG DISKURSA I UPROSTORAVANJE IDEOLOGIJE}

Istraživanja imenovanja i preimenovanja ulica i trgova kao simboličkih i političkih praksi otpočela su sedamdesetih i osamdesetih godina u okviru 
kulturne geografije u zapadnim akademskim zajednicama, i ovaj je interes bio omogućen tzv. kulturalnim obratom (cultural turn) u geografskoj disciplini. ${ }^{1}$ Jedan od najistaknutijih autora iz ove oblasti je izraelski geograf Maoz Azaryahu čiji je teorijsko-metodološki postupak postao neka vrsta osnove i za buduća istraživanja ovakve tematike, a koji je bio uvođen i u srodne društvene nauke, naravno sa određenim inovacijama i preinakama u pristupu. Takav je slučaj bio i u postjugoslovenskim zemljama kada je problematiku preimenovanja ulica i trgova kroz akademski diskurs među prvima istražila Dunja Rihtman-Auguštin 1995. godine, uvodeći time ovu oblast u korpus istraživanja hrvatske etnologije/kulturne antropologije, a objavljivanjem u beogradskoj Biblioteci XX vek 2000. godine pobudila je interes akademske zajednice za ovu temu i van granica Hrvatske. Nakon Rihtman-Auguštin, istraživanja naziva ulica kao sistema političkih simbola bila su tek sporadična i u hrvatskoj i u drugim etno-antropološkim zajednicama ovog područja, makar se intenziviralo istraživanje političkih krajolika shvaćenih u širem smislu (npr. Potkonjak i Pletenac 2007), te simboličkih mesta i konstrukcije urbanog identiteta kroz prizmu konkretnog (lokalnog) gradskog prostora (Gulin Zrnić 2009). S druge strane, nešto docnije u odnosu na RihtmanAuguštin, ulice kao politički simboli postale su zanimljive geografima u Hrvatskoj, koji u svojim tekstovima uglavnom prate Azaryahuovu istraživačku paradigmu, te sada postoji već solidna stručna produkcija na ovu temu u Hrvatskoj. ${ }^{2} \mathrm{U}$ drugim zemljama u regiji interesovanje za ovu problematiku, osim etnologa/antropologa i geografa pokazuju i istoričari, sociolozi i drugi. ${ }^{3}$ Ulice, njihova imena, i uopšte javni prostor postali su istraživačkom temom u više društvenih disciplina zahvaljujući "prostornom obratu" (spatial turn) koji je zahvatio mnoge društvene i humanističke nauke najkasnije od devedesetih godina. Tako postepeno dolazi i do, kako Čapo i Gulin Zrnić (2012: 12) navode, "oprostornjavanja" antropološkog pogleda, a prostorni se obrat vremenom transformisao u "prostorni trend", "koji na novi način osvjetljuje postojeći intelektualni krajolik i daje mjesta uprizorenjima novih interpretacija ili novim temama" (Gulin Zrnić 2012: 99). Prostorni obrat, a kasnije i trend, uključili su tako i etnologiju/kulturnu antropologiju u istraživanje društvenih (i političkih) praksi preko kojih se, kako Manojlović Pintar (2008) označava, "uprostoruju" ideologije, a službeno imenovanje (i preimenovanje) ulica i trgova jedna je od najrazvidnijih praksi ovakve vrste. Imenovanje (i službeno i neslužbeno) određenog putnog pravca, preobražava na taj način nesignifikantni prostor u (kulturno-značenjsko) mesto (shvaćeno

${ }^{1}$ Ovaj rad predstavlja rezultat istraživanja na projektu osnovnih istraživanja "Kulturno nasleđe i identitet" (177026) koji finansira Ministarstvo prosvete, nauke i tehnološkog razvoja Republike Srbije.

${ }^{2}$ Vidi Crljenko (2008), Stanić i dr. (2009), Mirošević (2011) i dr. Nazivima ulica bavili su se i istraživači iz drugih disciplina.

${ }^{3}$ Tako u Srbiji na ovu temu pišu Timotijević (2000), Stojanović (2008), Radović (2013) i dr. 
kao lokacija ispunjena značenjem - meaningful location). ${ }^{4} \mathrm{Na}$ ovaj način posmatrano, istraživanje politika identiteta kroz nazive ulica i sl., odonime (ili hodonime, odnosno imena ulica) kao političke simbole stavlja u ravan onoga što Lefebvre (1991) označava kao reprezentacije prostora (drugi prostor), a Soja (1996: 162) kao "drugiprostor" (područja reprezentacija i simbola), sa svim prednostima i ograničenjima koje ovi koncepti sa sobom nose i u interpretativnom i u teorijsko-metodološkom smislu.

Imenovanje ulica je, dakako, prvenstveno administrativni potez sa ciljem identifikacije i diferencijacije pojedinh putnih pravaca i omogućavanja prostorne orijentacije unutar naselja, no nazivi ulica i trgova predstavljaju i simbole koji zvaničnu istoriju i identitet transferiraju u semiosferu grada, čime zvanični nazivi u javnom gradskom prostoru predstavljaju i važnu komponentu službenih kultura pamćenja. Naravno, rečeno važi za oficijelne nazive putnih pravaca - sa nezvaničnim, vernakularnim označavanjem javnog prostora u gradovima stvari stoje unekoliko drugačije, i ovom prilikom, zbog ograničenog prostora, ovaj aspekt neformalnih društvenih praksi neće biti razmatran. Istraživanja imena ulica kao sistema simbola ukazuju na to da se službena gradska toponimija u organizovanoj modernoj državi "nikada ne konstituira spontano, nego je po pravilu zavisna od političkih ideologija i političke moći" (Rihtman-Auguštin 2000: 48-49). Ova relativno čvrsta povezanost između zvaničnih naziva gradskih prostora i službenih diskursa koincidira sa razvitkom nacija, te se u nizu evropskih zemalja sa uspostavljanjem nacionalnih država imena ulica postepeno transformišu iz spontanih organskih sistema u državno orijentisane sisteme koji naglašavaju naciju i istoriju, prateći istovremeni trend preobražaja prirodnog u istorijsko pamćenje (Milo 1996). "Tradicionalni" nazivi ulica u Evropi su obično bili vernakularni i povezani sa geografskom lokacijom ili funkcijom ulice ili trga, ili su se odnosili na određenu osobenost povezanu sa lokalnom topografijom ili istorijom. Daniel Milo navodi kako je ovakva praksa prekinuta već u rojalističkoj Francuskoj kada otpočinje designiranje gradskih ulica i po nelokalnim pojmovima i osobama iz dinastičkog panteona, a uskoro će političke, službene i urbane politike staviti pod svoju kontrolu imenovanje ulica i trgova. Mogućnosti odonima kao sredstva političke reprezentacije ubrzo su prepoznate i u drugim evropskim gradovima, te tako uskrsla pruska država 1813. godine propisuje da su nazivi ulica u stolnim gradovima državno vlasništvo, što je uslovilo "nacionalizaciju" ulične nomenklature, a imenovanje javnog prostora načinilo prvenstveno državnim, a ne lokalnim pitanjem (Katzur 1987: 5-6). Slično se dešava i u drugim evropskim zemljama u ovom periodu, pri čemu se imenima ulica memorijalizuju ne samo vla-

${ }^{4}$ Prema nekim tumačenjima "lokalitet se pretvara u mjesto činom imenovanja - koordinate upućuju na lokaciju, ime upućuje na mjesto” (Šakaja 2012: 113-117). 
dajuće dinastije i politički poredak, već i sama nacija. Najkasnije od kraja 19. veka imenovanje javnih prostora u većini evropskih zemalja postaje čvrsto vezano za nation-building, a isti slučaj se dešava i u savremeno doba u nizu vanevropskih, često mladih postkolonijalnih država. Do danas su službeni odonimi blisko asocirani sa vladajućim ideologijama u društvu, i ova vrsta simboličkog monopola politike će tek povremeno biti osporavana.

Interes za istraživanje preimenovanja ulica i trgova u zadnjim decenijama proizlazi prvenstveno iz tri grupe društveno-istorijskih razloga: prvo, proces dekolonizacije je imao vanredan uticaj na politike prostora u pojedinim zemljama; isto tako, etnopolitički konflikti su u mnogim državama uslovljavali znatnu simboličku intervenciju u javnom prostoru koji je bivao predmetom sporenja između različitih etnonacionalnih skupina; te na kraju, prelaz evropskih socijalističkih društava u kapitalistički sistem doveo je do suštinskog preoblikovanja identiteta i konstrukcije novog kolektivnog pamćenja, prvenstveno na neposrednu prošlost (Stanić i dr. 2009: 91-92), čime su javna spomenička baština iz prethodnog perioda i imena ulica i trgova koja su asocirala na raniji sistem, bila među prvim i najvidljivijim žrtvama tranzicije. U ovakvim slučajevima dolazi do dva komplementarna procesa: komemoracije (commemoration), odnosno odonimskog označavanja, te dekomemoracije (decommemoration), odnosno brisanja određenih uličnih naziva, pri čemu smena starih političkih simbola novima jasno naznačuje identitetsko-političke preokrete u određenom periodu i prostoru (Azaryahu 1986). Masovno preimenovanje javnih prostora u državama bivše Jugoslavije primarno je proishodilo iz pomenutog okvira postsocijalističke transformacije, slično kao i u mnogim drugim zemljama Srednje i Istočne Evrope, te u zonama vojnog konflikta kao rezultat rata i međuetničkih sukoba. Istovremeno sa urušavanjem socijalističkog društveno-političkog uređenja došlo je i do raspada tadašnje savezne države, te, za razliku od većine drugih postsocijalističkih zemalja, dolazi do dvostruke transformacije šireg društvenog konteksta i "tranzicije" iz socijalizma u kapitalizam, i opšteg preoblikovanja nacionalne paradigme uklanjanjem jugoslovenskog i konstrukcijom novog i sada ekskluzivnog (etno)nacionalnog okvira. Uspostavljanje nove hegemone političke ideologije skupa sa izgradnjom novih nacionalnih narativa imalo je znatne učinke na simbolički javni prostor, pa tako i na masovne izmene u nazivima ulica, trgova, čitavih naselja, pa otuda i utisak savremenika da se radilo o zaista vanrednoj političkoj intervenciji u gradsko nazivlje, čak i kada se uporedi sa većinom drugih postsocijalističkih zemalja. Međutim, koliko god se činilo da se radi o vanrednim postupcima, treba imati na umu da su preimenovanja sličnog opsega bila prisutna i nakon 1945. godine. Štaviše, često se zadnjih godina moglo čuti kako se aktuelna preimenovanja i sprovode sa ciljem revizije ranijih masovnih, a kako se još navodi, i "ideoloških i nepravednih" promena u nazivima ulica tokom socijalističke epohe. Naravno, 
savremeni inicijatori kreiranja javnog prostora svoje postupke vide kao navodno neideološke i neutralne, i nezavisne od političke volje, što oni naravno nisu, niti mogu biti. I savremeni "preduzetnici identiteta" (Jordan 2006: 2-3), sebe predstavljaju kao nepolitičke i kompetentne društvene aktere, na isti način kao što su to činili ne samo njihovi prethodnici za socijalizma, već i u svim ranijim periodima prošlosti, a treba znati da su veliki valovi imenovanja i preimenovanja bili tipični ne samo za doba velikih društvenih političkih lomova kao što su, na ovom prostoru, stvaranje Kraljevine Srba, Hrvata i Slovenaca, okupacija 1941., oslobođenje 1945. i dr., već i za periode prividne političke kolotečine. ${ }^{5}$

\section{PARCIJALNA I OPSEŽNA REVIZIJA ULIČNOG KOMEMORATIVNOG FONDA}

Najnovija travestija uličnih naziva koja se na ovdašnjem području počela sprovoditi od 1990. godine je svoj vrhunac imala u prvoj polovini devedesetih, npr. u Hrvatskoj i pojedinim gradovima Bosne i Hercegovine, u prvoj polovini 2000-ih, npr. u Srbiji i Crnoj Gori, a zadnjih nekoliko godina ne prisustvujemo en-bloc masovnim preimenovanjima ulica, osim u određenim izuzecima kao što su npr. Skoplje i pojedini makedonski gradovi. Naravno, sporadične javne diskusije vezane za pokušaje imenovanja i preimenovanja pojedinih ulica i trgova, kao što su npr. aktivnosti inicijative "Krug za trg" u Zagrebu, ili poništavanje imenovanja Titove ceste u Ljubljani, jasno pokazuju da je simboličko označavanje javnog prostora putem (pre)imenovanja kontinuiran i, izgleda nedovršen proces koji je katkad veoma intenzivan, a ponekad, kao zadnjih godina, tek prividno ograničen na pojedinačne slučajeve. ${ }^{6}$ Ovakvi postupci uprostoravanja novih političkih i nacionalnih ideologija su varirali na postjugoslovenskom prostoru, već u zavisnosti od vremenskog perioda, države ili pojedinog grada, pri čemu treba imati na umu da i lokalna politička konjunktura, a ne samo širi nacionalni okvir znatno utiču

${ }^{5}$ Tako se npr. u Zagrebu 1928. (Stanić i dr. 2009: 96), te u Beogradu 1930. godine (Beogradske opštinske novine 48-2/1930), (pre)imenuje preko stotinu ulica u jednom navratu, i to u godinama relativnog političkog zatišja.

${ }^{6}$ Odbornici Mestne občine Ljubljana su 2009. odlučili da jednu novotrasiranu ulicu nazovu po Josipu Brozu Titu (vođi antifašističkog pokreta i socijalističke Jugoslavije), a po kojem se do 1991. zvala središnja gradska ulica. Ovo je izazvalo oštre reakcije kod desnih političkih grupacija, koje su se ovakvom činu suprotstavile i podneskom Ustavnom sudu Slovenije koji je dao mišljenje da je imenovanje Titove ceste neustavno (nakon čega su gradski odbornici ovoj ulici dali drugačiji naziv). Zagrebački Trg Maršala Tita nije pak bio predmetom prominentnijeg javnog ili političkog sporenja od početaka višestranačja do 2008. godine, od kada inicijativa "Krug za trg" (koja okuplja građane, različite organizacije, te nekoliko desnih političkih stranaka) traži preimenovanje ovog trga s ciljem dekomemoracije Tita iz središta grada - ova inicijativa (za sada) nije polučila konkretnije rezultate. Više detalja o ljubljanskim i zagrebačkim prostornim sporenjima vezanim za Tita vidi u Radović (2013). 
na osobenosti preimenovanja - dovoljno je uporediti u Hrvatskoj npr. Split i Rijeku, a u BiH "Zapadni" i "Istočni" Mostar. Tako je u Splitu za samo tri godine (1990.-1993.) preimenovano oko 150 ulica koje su gotovo listom komemorisale partizanski pokret i socijalističke tradicije (Markovina 2014); s druge strane, u Rijeci je u periodu 1991-1995. (pre)imenovano (tek) 50 ulica i trgova, od kojih je njih 26 asociralo na Narodnooslobodilačku borbu (NOB), socijalizam ili Jugoslaviju. ${ }^{7}$ U Mostaru pak, u zapadnim četvrtima koje su za rata pod kontrolom držale snage Hrvatskog vijeća obrane (HVO), nove nazive dobile su gotove sve gradske ulice već do kraja 1995, dok u istočnim kvartovima koji su u toku rata bili zona Armije $\mathrm{BiH}$, do danas jedva da je nekoliko ulica dobilo nova imena. ${ }^{8}$ Ako bismo pak pokušali sumirati ove procese (pre)imenovanja javnog prostora u odnosu na nove nezavisne države konstituisane nakon raspada Jugoslavije, mogli bismo okvirno utvrditi postojanje tri preovlađujuća obrasca prilikom nove odonimske komemoracije kao vida politike identiteta i pamćenja.

Prvi obrazac bismo mogli označiti kao parcijalnu korekciju memorije, pri kojoj dolazi do deložiranja socijalističke i jugoslovenske simbolike kao centralnih identitetskih markera u urbanom nazivlju, ali ne i do sveobuhvatnog deinstaliranja takvih naziva - radi se uglavnom o postupcima preimenovanja središnjih gradskih ulica i trgova novim, "podesnijim" nacionalnim simbolima, uz istovremeni ostanak mnogih odonima koji asociraju na prethodni sistem. Ovakav obrazac moguće je locirati pogledaju li se npr. glavni gradovi Slovenije i Crne Gore. Tako u Ljubljani 1991. dolazi do preimenovanja 46 ulica, da bi do kraja decenije nove nazive dobijalo tek oko 5 ulica godišnje. ${ }^{9}$ Ovim prvim dekomemoracijskim potezima prigodno su sklonjeni sa središnjih gradskih ruta, pored ostalih, Josip Broz Tito, Edvard Kardelj (nezvanično druga najbitnija osoba u jugoslovenskoj nomenklaturi i vodeći ideolog jugoslovenskog socijalizma) i Boris Kidrič (jedan od vođa antifašističkog pokreta u Sloveniji i visoki funkcioner u poraću), zajedno sa pojmovima kao što su Revolucija, Osvoboditva, VII korpus i sl., istovremeno gubeći svoje dotada neprikosnovene pozicije iz poratne slovenačke političke mitologije. No, ovakve vrste uličnih dekomemoracija su predstavljale više prostornu marginalizaciju nego brisanje socijalističke simbolike iz javnog prostora, a što je bilo prisutno i u nekim drugim gradovima u Sloveniji. ${ }^{10}$ Do kraja 1991.

${ }^{7}$ Podaci iz Službenih novina (Primorsko-goranske županije) od 15. 7. 1991, 7. 10. 1991, 8. 11. 1993. i 24.7. 1995.

${ }^{8}$ Detaljnije vidi Palmberger (2012) i Radović (2013).

${ }^{9}$ Podaci iz: Uradni list Socijalistične Republike Slovenije i Uradni list Republike Slovenije 20/91, 21/91, 66/95, 22/97, 18/98, 47/99.

${ }^{10}$ Mrežna baza podataka statističkog ureda Slovenije (stranica: stat.si/krajevnaimena) 2012. godine ukazuje na i dalje znatnu prisutnost osoba i pojmova direktno ili indirektno povezanih sa Narodnooslobodilačkim pokretom (NOP) i slovenačkim Oslobodilačkim frontom (Osvobodilna fronta - OF) 1941-1945., pa tako u gradskim naseljima u Sloveniji i dalje postoji 29 Partizanskih ulica i 24 Partizanske ceste. 
najbitniji gradski pravci su dobili imena koja nisu nedvosmisleno ukazivala na Narodnooslobodilački rat (NOR) i posleratnu istoriju u Sloveniji, prigodno revidirajući glavne simbole u gradskom prostoru, pri čemu je došlo do tek parcijalnog otklona od simbolizma NOR-a pošto je većina naziva u gradu povezanih sa oslobodilačkim pokretom 1941-1945. ostala netaknuta. Slično tome, i u Crnoj Gori dolazi do korekcije naziva pojedinih, uglavnom središnjih prometnica - npr. u Titogradu, a od 1992. Podgorici, ${ }^{11}$ u prvih deset godina tranzicije, nova imena je dobilo tek nekoliko većih ulica i trgova čiji dotadašnji nazivi nisu bili u skladu sa tada preovlađujućim političkim pogledima, te se tako ukida naziv Trga Edvarda Kardelja (a jedan gradski trg imenuje po Golootočkim žrtvama), bulevar u kojem se nalazio gro organa vlasti gubi naziv po Blažu Jovanoviću (dugogodišnjem socijalističkom rukovodiocu Crne Gore) te postaje Nemanjina obala (po rodonačelniku srpske feudalne dinastije Nemanjića) i sl. Ni u drugim crnogorskim gradovima ne dolazi do obimne revizije uličnog nazivlja, ${ }^{12}$ ali će sa trasiranjem novih strategija izgradnje savremenog crnogorskog identiteta i uzletom pokreta za nezavisnost nazivi podgoričkih ulica iskusiti nešto masovnija preimenovanja. Tako polovinom prošle decenije nova imena dobijaju centralni podgorički trg ranije imenovan po narodnom heroju Ivanu Milutinoviću (postavši Trg Republike), dugačke gradske ulice i bulevari imenuju se po vladarima iz crnogorskih dinastija Petrović i Crnojević i sl., ali i tada dolazi više do preslagivanja simbola po novim "nacionalnim prioritetima" nego do ukidanja socijalističke simbolike (pri čemu su dekomemorisani borci NOR-a redovno dobijali svoje ulice u drugim gradskim kvartovima).

Obrazac odonimskih politika (nacionalnog) identiteta prema kojem se središnji prostorni simboli (glavni trgovi i ulice) imenuju "adekvatnijim" i novijim političkim simbolima, pri čemu većina socijalističkog komemorativnog fonda biva "puštena na miru" (čime dolazi do parcijalne korekcije kolektivnog pamćenja na recentnu prošlost) tipičan je i za mnoge gradove u Makedoniji. Tako se u Skoplju ${ }^{13}$ do polovine devedesetih preimenuju 4 trga, 7 bulevara i 34 ulice, kao i jedan most (most Oktomvriska revolucija

Uzmu li se u obzir odonimi koji komemorišu samo osobe, može se uočiti da je četvrti odonimski najčešće memorijaliziran Slovenac Karel Destovnik Kajuh (književnik i narodni heroj), deveti France Bevk (pisac, španski borac i pripadnik NOP), jedanaesti Oton Župančič (književnik i aktivni pomagač OF), dvanaesti Boris Kidrič, četrnaesti Tone Tomšič (jedan od vođa OF) itd.

${ }^{11}$ Podaci o nazivima ulica i trgova u Titogradu, odnosno Podgorici dobijeni su sa mapa: Titograd plan grada, Geodetski zavod SR Slovenije. Ljubljana 1988; Podgorica - plan grada. Direkcija za nekretnine Republike Crne Gore. Podgorica 1998; Plan grada Podgorice, Intersistem-Kartografija. Beograd 2004; Podgorica - plan grada, Turistička organizacija Podgorice. Podgorica 2007.

${ }^{12}$ Po sličnom obrascu u starom crnogorskom glavnom gradu, Cetinju, Trg maršala Tita postaje Trg kralja Nikole, Bulevar Lenjina - Bulevar crnogorskih junaka itd.

${ }^{13}$ Podaci o nazivima skopskih ulica dobijeni su iz službenih odluka o preimenovanjima (Služben glasnik na grad Skopje 6/2012, 15/2012), te sa mapa: Plan na grad Skopje, Skopje: Turistički sojuz (1988); i Plan na grad Skopje, Skopje: Trimaks (2006). 
je postao 8. Septemvri) i gradsko naselje (kvart Sinđelić je dobio novo ime Metodija Andonov Čento). ${ }^{14}$ No, 1996. godine Ustavni sud Makedonije poništio je odluke o preimenovanju skopskih ulica zbog kršenja procedure i neusaglašenosti postupka preimenovanja sa zakonskim propisima, što dovodi do višegodišnjeg zastoja u (de)komemorativnim prostornim praksama. Ovo zatišje prekinuto je 2012. godine sa daljim zahuktavanjem službenih politika "antikvizacije" makedonskog nacionalnog identiteta (a paralelno sa realizacijom arhitektonsko-spomeničkog projekta Skopje 2014), kada Sovet na Grad Skopje (gradska skupština) u javnost izlazi sa spiskom od čak 254 novih (potencijalnih) imena ulica, uz najavu da se sprema njih još hiljadu! ${ }^{15}$ Do kraja te godine na gradske ulice je instalirano oko 30 ličnosti i pojmova koji su "dogovoreni" između makedonskih i albanskih političara u Skoplju, sa ambicijom da se sa ovakvim komemorativnim praksama nastavi i u budućnosti. Ovo znatno ambicioznije krojenje prestoničke simboličke mape koje cilja na opsežnu preradu političko-nacionalnog imaginarija, a ne tek njegovu modifikaciju kao što je do tada bio slučaj, približava najnovije odonimskosimboličke prakse u Makedoniji onima koje su ranijih godina sprovođene u velikom broju gradova Srbije i Hrvatske.

Drugi obrazac "uličnog uprostoravanja ideologije" koji je bio preovlađujući u Hrvatskoj i Srbiji, makar sa neujednačenom implementacijom nove političke i nacionalne paradigme u javni prostor u različitim područjima i gradovima, je opsežniji od prethodno pomenutog utoliko što je dolazilo do još masovnijeg preimenovanja ulica i trgova, i suštinskijeg raskida sa odonimskom baštinom socijalizma i Jugoslavije. Pri tom je on u Hrvatskoj svom silinom počeo bivati uvođen već po prvim višestranačkim izborima, a počeo lagano gubiti ritam od druge polovine devedesetih godina, dok je u Miloševićevoj Srbiji nešto manje ambiciozna revizija pamćenja preko uličnih naziva dobila novi zamah nakon petooktobarskog prevrata 2000. godine. O ovome govore i šampionske godine u takmičenju "Preimenujmo što više ulica": u Zagrebu je to 1993. kada je nov naziv dobilo gotovo 180 ulica (Stanić i dr. 2009: 104), a u Beogradu je klimaks preimenovanja bio 2004. kada su "prekrštene" 192 ulice. ${ }^{16}$ U ovim, i mnogim drugim gradovima sproveden je sveobuhvatni otklon i od socijalizma i od jugoslovenske ostavštine, i više se

\footnotetext{
${ }^{14}$ Centralni skopski trg Maršal Tito dobio je novo ime Makedonija (kao i prislanjajuća ulica), bulevar AVNOJ je, sasvim logično, postao bulevar ASNOM (na mjesto vrhovnog antifašističkog organa Jugoslavije komemorisan je srodni politički organ za Makedoniju), bulevar Jugoslovenska narodna armija (JNA) je nazvan po svetom Klimentu Ohridskom, bulevar Jugoslavija postaje bulevar Nikola Karev (po rodoljubu iz doba otomanske vlasti), bulevar Marks i Engels - VMRO (Vnatrešna Makedonska Revolucionerna Organizacija), a bulevar Edvard Kardelj - Aleksandar Makedonski.

${ }^{15}$ Slične inicijative pokrenute su i u drugom najvećem makedonskom gradu, Bitolju.

${ }^{16}$ Službeni list grada Beograda 2004/2, 2004/4 i 2004/5. O preimenovanjima ulica i trgova u ovom periodu u Zagrebu detaljno vidi Rihtman-Auguštin (2000) i Stanić i dr. (2009), a u Beogradu Radović (2013).
} 
radilo o sistematskom uklanjanju podsetnika na ovu istorijsku epohu nego o njihovom skrajnjivanju. Politike prostora sprovode se više "u širinu", ne samo sklanjanjem udarnih odonimskih markera prošle epohe u gradskom tekstu, već i masovnim brisanjem uličnih naziva koji asociraju na jugoslovenski socijalizam kroz čitav gradski prostor. Dok su se u većini gradova Crne Gore, Makedonije i Slovenije sprovodile politike prostora koje su novim odonimima simbolički u prostoru nadograđivale ranije nacionalne ideologije (konstruisane i tokom socijalističke epohe), u mnogim hrvatskim i srpskim gradovima najčešće se radilo o negiranju starijeg nacionalno-političkog imaginarija konstituisanog unutar jugoslovenskih i socijalističkih okvira sprovodila se prostorna strategija svojevrsnog prevazilaženja, preskakanja socijalističke epohe, kao nečega što ne treba tek staviti po strani, već što je moguće više zaboraviti. ${ }^{17}$ Ove odonimske politike simbola praćene su istovremenim zapuštanjem ili devastacijom spomeničke baštine podignute nakon 1945, te etabliranjem koncepta "normalnog", prisutnog i u mnogim drugim postsocijalističkim zemljama, koji pozicionira socijalizam i njegovu zaostavštinu kao nešto što treba prevazići ili prebrisati (Fehervari 2002), a koji se uglavnom "normalizovao" u Hrvatskoj već s početka devedesetih, a u Srbiji nakon 2000. godine (pri čemu je i kritika i parcijalna revizija novouspostavljenog koncepta "normalnosti", makar u prostorno-identitarnom smislu, nešto ranije počela izranjati u Hrvatskoj nego Srbiji).

Nova odonimska "normalnost" trebala je i nove političke simbole koji su u mnogim drugim srednjo-istočnoevropskim gradovima nalaženi jednostavnom restauracijom "prekomunističke" urbane nomenklature. Restaurativne identitetsko-memorijalne prakse parcijalno su i bile sprovođene u mnogim gradovima u našoj regiji, ali se nije radilo o preovlađujućem i sveobuhvatnom trendu. Naime, "prekomunistički" ulični simboli (ako se izuzme period kvislinških uprava koji, uprkos jakim zamasima istorijskog revizionizma i rehabilitacije kolaboracionizma širom jugoistočne Evrope, nije uziman kao simbolički osnov za izgradnju najnovijih politika gradskog prostora) bili su iz perioda "stare", monarhističke Jugoslavije, stoga parcijalno nepodesni za izgradnju savremenih nacionalnih identiteta putem simbolizacije gradskog prostora, s obzirom na to da se i dalje aktuelni hegemoni ideološki obrazac zasniva na formuli "antisocijalizam/antikomunizam plus antijugoslavenstvo" (Jovanović 2007: 169), čime znatni segmenti političkog

17 Tako je u Hrvatskoj do 2007. godine druga odonimski najčešće komemorisana osoba bio Vladimir Nazor (pisac i prvi predsjednik Narodne Republike Hrvatske), ali su ostale istorijske ličnosti jasno povezane sa NOB-om i socijalizmom znatno slabije bile zastupljene u uličnoj nomenklaturi hrvatskih gradova: Ivan Goran Kovačić - književnik i pripadnik antifašističkog pokreta (13. najčešći odonim skovan po osobi), August Cesarec - pisac i istaknuti član Komunističke partije (26), Andrija Hebrang - jedan od vođa antifašističkog pokreta u Hrvatskoj (29), Mihovil Pavlek Miškina - književnik, seljački tribun i žrtva fašističkog terora (35), Ivo Lola Ribar - lider komunističke omladinske organizacije za rata (37) itd. (Letica 2007). 
simbolizma iz obe inkarnacije jugoslovenske države postaju neadekvatni u savremenom političkom prekrajanju grada kao teksta. Stoga se simbolički materijal u ovakvim postupcima nalazi u još daljim istorijskim periodima, iz kojih se pojedina imena (i pojmovi) instaliraju na gradske ulice. Tako se u mnogim srpskim gradovima poseže za odonimskim označiteljima povezanim sa nemanjićkom feudalnom državom i nezavisnom srpskom državom 19. i 20 veka, a u gradovima u Hrvatskoj masovno su imenovane ulice po hrvatskim narodnim vladarima (Grgin 2007). Simbolički ulični "preskok" preko socijalističke/jugoslovenske epohe u, danas kurentniju zamišljenu/ izmišljenu "zlatnu" (etno)nacionalnu prošlost, sasvim je u skladu i sa drugim politikama nacionalnog identiteta na ovom području, koje se zasnivaju i na strategiji "simulacije kontinuiteta" kojom se simboličke osnove izgradnje savremenih identiteta nalaze u ranijim istorijskim tradicijama i elementima, uz često ignorisanje najrecentnije kulturne i/ili ideološke baštine (Malešević 2008: 17). Ta najnovija zlatna nacionalna prošlost na gradskim je ulicama uključivala i odonimske spomenike pojedinim tzv. kontroverznim istorijskim osobama (i pojmovima) koje se posredno pokušava ugurati u nove etno-nacionalne panteone kačenjem uličnih tabli sa njihovim imenima. Devedesetih je godina više hrvatskih gradova tako dobilo ulice (hrvatskog književnika) Mile Budaka, koji je najpoznatiji kao visoki funkcioner tzv. Nezavisne države Hrvatske/NDH (te nekoliko ulica 10. travnja, po datumu proglašenja $\mathrm{NDH}$ ), pri čemu u zadnjih desetak godina dolazi do postepenog ukidanja ovakvih uličnih naziva, a u Srbiji se povećava broj ulica nazvanih po Draži Mihailoviću (vođi kolaboracionističkog četničkog pokreta), Milanu Nediću (šefu kvislinške vlade u Srbiji 1941-1944), i nekim drugim pripadnicima kolaboracionističkih i kvislinških pokreta i snaga u Drugom svetskom ratu. Ovaj (ekstremni) pol novog odonimskog označavanja bio je prisutan i u pojedinim drugim postsocijalističkim gradovima u Evropi (naporedo sa sveopštim zamahom revizije prošlosti i u ovim zemljama), i čitava odonimska prekonfiguracija gradova u Hrvatskoj i Srbiji (najčešće širokog obuhvata), te Crnoj Gori, Makedoniji i Sloveniji (uglavnom parcijalna) u znatnom je skladu sa sličnim prostornim politikama (novog) nacionalnog identiteta koje su u različitim opsezima provođene širom Srednje i Istočne Evrope. ${ }^{18}$

${ }^{18} 0$ sličnim praksama preimenovanja ulica u "postsocijalističkim" gradovima van "postjugoslovenskog" područja detaljnije vidi Arbenbright (1999), Light (2004), Palonen (2008). 


\section{POTPUNI PREKID: ETNOPOLITIČKA MONOPOLIZACIJA SIMBOLIČKOG PROSTORA}

I dok su prakse (de)instaliranja simbola na ulicama brojnih gradova prethodno pominjanih država podosta korespondirale sa sličnim postupcima u drugim postsocijalističkim zemljama, u pojedinim područjima bivše Jugoslavije sprovodile su se (a katkad se i dalje sprovode) odonimske (de)komemoracije koje naizgled nemaju savremenih pandana. Treći obrazac uličnih (pre)imenovanja tipičan je za zone najintenzivnijih ratnih dejstava i najradikalnijih etnonacionalnih politika, odnosno za Kosovo, manji bosansko-hercegovački entitet, i pojedine gradove Federacije BiH. Osim distanciranja ili negiranja baštine jugoslovenskog socijalizma koje postoji i u drugim postjugoslovenskim zemljama, politike prostora u mnogim gradovima u ovim područjima imale su i dodatni, možda i primarni cilj: deložiranje odonimskih tragova konkurentskih etničkih grupa, odnosno kreiranje uličnih mapa gradova koje simbolički pokušavaju da označe njihov jednonacionalni karakter. Ovo je osobeno za mnoge gradove u kojima je politika etničkog čišćenja zaista i sprovođena, ali i za pojedina naselja koja i dalje predstavljaju prostor suparništva između konkurentskih etničkih grupa, odnosno njihovih političkih vođa. Kako se ovakve "ulične" politike etnonacionalnog identiteta provode mogu pokazati osnovni podaci iz Banje Luke u kojoj je samo od početka rata do 1997. nove nazive dobilo 240 od oko 400 banjolučkih ulica. ${ }^{19}$ Do 1990. među imenima ulica u Banjoj Luci njih 114 je bilo nazvano po znamenitim Srbima, 81 po Bošnjacima (Muslimanima), te 25 po Hrvatima. S druge strane, 2007. situacija je bila ovakva: 338 ulica nosilo je nazive prema Srbima, 20 po znamenitim Hrvatima, a po Bošnjacima, odnosno bosanskim muslimanima, nazvano je njih ukupno tri. Slične intencije sprovedene su i u Prištini, s tim da je u ovom gradu u roku od 10 godina došlo do dvostrukog "etničkog čišćenja" naziva ulica. ${ }^{20} \mathrm{U}$ periodu od 1990. do 1999., u doba vlasti Slobodana Miloševića, na Kosovu, od svih prištinskih ulica po znamenitim Albancima nazvano je njih tek deset. S druge strane, nakon ulaska NATO snaga i uspostavljanja kosovskih vlasti u ovom gradu, situacija se tek izokrenula, i po Srbima i Crnogorcima je u Prištini bilo imenovano tačno deset ulica - izgleda kao svojevrsna "odonimska osveta bez kamate". I u prostorima direktnog sudara doskora zaraćenih grupa sprovodile su se ovakve odonimske intervencije

${ }^{19}$ Podaci o nazivima ulica u Banjoj Luci nađeni su na mapama Banja Luka: plan grada, NIP Glas. Banja Luka 1979, i Banja Luka - plan grada, Merkur-SV. Beograd 2006, te u registru naziva banjolučkih ulica na mrežnoj stranici zoranmackic.com/wp-content/uploads/banjalucke-ulice1.pdf (pristup decembar 2010.).

${ }^{20}$ Podaci o imenima ulica i trgova u Prištini nađeni su na zvaničnoj mrežnoj stranici Opštine Priština (Komuna e Prishtinës) kojoj je pristupljeno u novembru 2009. godine - Lista e emërtimeve të rrugëve të Prishtinës (URL: prishtina-komuna.org), i na mapama: Priština - plan grada, Jedinstvo, Priština 1996, i Harta e Prishtinës, Enti për punë gjeodezike dhe fotogrametrike, Priština 2002. 
posebne vrste i namjene. To je vidno npr. u slučaju Mostara u čijim su zapadnim četvrtima pod kontrolom HVO-a već 1995. skoro sve ulice dobile nova imena, jasno gotovo isključivo hrvatskog karaktera, a među njima i najmanje pet istaknutih likova povezanih sa tzv. NDH. ${ }^{21}$ Ulična upotreba nosilaca šovinizma i kolaboracije iz Drugog svetskog rata nije mimoišla ni mnoge gradove u Republici Srpskoj (RS), između ostalog i Istočno Sarajevo u kojem se može prošetati i ulicom đenerala Draže Mihailovića, vojvode Momčila Đujića (po istaknutom četničkom vođi iz Drugog svetskog rata), Ravnogorskom i sličnim alejama. ${ }^{22}$ Ovakva nacionalna isključivost pri preimenovanjima često razrušenih ulica bez stanovnika bila je često praćena sa koordinisanim politikama prostora i u vidu uništavanja spomeničke baštine NOB-a i religijskih objekata suparničkih grupa, a u slučaju RS i masovnim preimenovanjem gradova sa prefiksom bosanski ili gradova i gradskih kvartova čija imena imaju muslimanski ili turkofoni prizvuk - ovaj će alternativni zemljopis tek parcijalno biti ukinut odlukom Ustavnog suda BiH iz 2004. ${ }^{23}$

$\mathrm{S}$ druge strane, u mnogim gradovima sa bošnjačkom većinom, odnosno naseljima koja su kraj rata dočekala pod zaštitom Armije BiH, preimenovanja ulica nisu bila ni približno brojna kao u drugim krajevima Bosne, a simbolički otklon od socijalizma i druga dva bosanskohercegovačka naroda bio je nešto manji. 0 tome govori i podatak iz 2007. da su u gradovima sa bošnjačkom većinom osobe koje su najčešće memorijalizovane bile Josip Broz Tito i Džemal Bijedić (poznati komunistički rukovodilac iz BiH i jugoslovenski premijer), a najčešći naziv ulice bio Omladinska. ${ }^{24}$ Istovremeno, u Sarajevu je od kraja opsade do 2000. nove nazive dobilo 403 od ukupno 1044 sarajevske ulice, što predstavlja jednu od obimnijih kampanja preimenovanja na postjugoslovenskom prostoru. ${ }^{25}$ Međutim, sarajevski je slučaj osoben po tome što su masovno restaurirana stara imena ulica, često čak iz kasnog otomanskog i ranog austrougarskog razdoblja, a što u principu nije bilo pravilo u većini drugih gradova, te da su većinom u pitanju bile starije vernakularne i lokalne oznake. Istovremeno, iako je znatno smanjen udeo odonima koji su komemorisali nebošnjačke osobe, u Sarajevu se nije išlo na sistematsko uklanjanje oznaka povezanih sa drugim narodima $\mathrm{BiH}$ i bivše Jugoslavije, što je gotovo bilo pravilo u nizu gradova, ne samo u Bosni. Progon prostornih simbola

${ }^{21}$ Podaci iz: Službeno glasilo Općinskog vijeća Općine Mostar 1-2/4 (1995), i 5/4 (1995).

${ }^{22}$ Podaci o nazivima ulica u Istočnom Sarajevu preuzeti su sa službenih stranica opština Istočno Novo Sarajevo i Istočna Ilidža (opstinains.net i istocnailidza.net) (pristup 2010.).

${ }^{23}$ Sud je naložio ukidanje naziva gradova sa prefiksom "srpski" obrazlažući to mišljenjem da ovakva imena naselja krše ustavna prava pripadnika druga dva konstitutivna naroda na jednakost, i pravo svih građana da ne budu podvrgnuti diskriminaciji (Feldman 2005: 649-650). Sličnom političko-topografskom logikom implementiranom u BiH, u najnovije doba i kosovski gradovi čiji nazivi na albanskom jeziku imaju očitu slovensku jezičku osnovu dobijaju nova, "adekvatnija” imena.

${ }^{24}$ T. Šikanjić i dr. “Omladinska najčešća ulica”. Nezavisne novine, 27. 10. 2007.

${ }^{25}$ Detaljno vidi Robinson i dr. (2001). 
(odonima, ali i ekonima, naziva naselja) koji nedvosmisleno, ili pak samo posredno asociraju na etničke grupe čije se aktuelno ili istorijsko prisustvo na datom prostoru ovim želi izbrisati ili skrajnuti, čini se u savremeno doba kao postjugoslovenski "ekces", ali slične ideološko-prostorne prakse se i danas sprovode u drugim zemljama - dovoljno je pogledati npr. Izrael i okupirane palestinske teritorije Zapadne obale, Golana i Gaze, u kojima je imenovanje naselja sredstvo legitimacije izraelske vlasti, i najčešće se sprovodi imenovanjima po toponimima iz biblijskih i talmudskih tekstova, ili po izraelskim vojnim herojima i likovima savremenog cionizma (Cohen i Kliot 1992). Sa sličnim motivima sprovodila su se i (pre)imenovanja ulica u mnogim gradovima u Izraelu i na okupiranim teritorijama (Azaryahu i Kook 2002). Tradicionalno su preimenovanja i naselja i ulica bila sredstvo legitimisanja željene ili postignute etnonacionalne slike na određenom području i u Evropi, što je jasno pogledaju li se ulični nazivi u mnogobrojnim srednjoevropskim i balkanskim gradovima koji su se po raspadu Austrougarske i Otomanske države našli u "novim" nacionalnim državama, ili u kojima je nakon 1945. godine došlo do drastične transformacije etnodemografskih prilika (takav je slučaj bio i u mnogim područjima bivše Jugoslavije u ovim istorijskim razdobljima). Imajući ovo u vidu, najnovije identitetske politike prostora (i odonimske i ekonimske) u jugoistočnoj Evropi zapravo nisu toliko ni savremene, a ni originalne (a ni tipično "balkanske"), pošto su mnogo ranije već bile sprovođene u nizu evropskih zemalja.

Sva tri pomenuta obrasca odonimske rekonfiguracije savremenog identiteta i kolektivnog pamćenja bila su implementirana uporedo sa drugim identitetskim politikama u prostoru (devastacija prethodne spomeničke baštine, i konstrukcija nove), kao i sa onima u drugim javnim sferama. Prominentnost i masovnost (pre)imenovanja ulica i trgova (počesto i čitavih gradova i drugih naselja) proizlazi i iz jednostavnosti ovakvog postupka - simbolička i praktična osobenost ovakvih praksi dobro je sublimirana iskazom da "ulična tabla predstavlja najjeftiniju vrstu spomeničkog kipa" (Light i dr. 2002: 140), što je između ostalog omogućilo i proliferaciju novih uličnih naziva od 1990. godine naovamo. Masovno preimenovanje javnih prostora na postjugoslovenskom području predstavlja tek najučestalije i najraširenije prostorno sredstvo službeno podržavanih politika (nacionalnog) identiteta u zadnjih 25 godina, koje su se intenzivirale sa formiranjem novih nacionalnih država, te i nakon svršetka ratova dominiraju javnim diskursima. Ovaj svojevrsni "teror" (nacionalnih) identiteta, ali i različitih oblika kolektivnog pamćenja, u drugi plan stavlja mnoge druge društvene pojave i prakse koje bivaju skrajnute u javnoj, a katkad i u akademskoj sferi. Dok su identitetska i pitanja kulture pamćenja, pa time i njihovih prostornih emanacija, na našem području postala udarna nakon što je "nacionalni identitet kao neprikosnovena, takoreći sveta vrednost došao s ratom devedesetih, kao jedna od 
njegovih glavnih tekovina" (Čolović 2014: 10), ni širi evropski prostor nije bio imun na "fetišizaciju" identitetskih pitanja koja su i globalno izronila kao (prividno) primarna u razdoblju tekuće modernosti, kada se usredsređivanje na pitanja različitih (osobnih i kolektivnih) identiteta i kulturno-simboličkih pozicija javlja istovremeno i kao rezultat i kao reakcija na ubrzavanje globalizacije i vremensko-prostorne kompresije. U tom smislu, klasično shvaćen geografski i urbani prostor može i u budućnosti biti interesantna ravan za implementaciju službenih kultura pamćenja i identiteta koje hibridizacijom drugih javnih sfera postaju sve manje ekskluzivnim domenom klasičnih političkih/službenih aktera. Politička simbolizacija javnog prostora (i njegovim pre-imenovanjem) tako potencijalno i nadalje može biti, ne samo na ovdašnjem području, intenzivna i učestala društvena praksa (nezavisno od velikih društveno-političkih preokreta), istovremeno i kao relativno sigurna luka službeno podupiranih identitetskih i memorijalnih politika, ali i kao svojevrsni simboličko-prostorni zastor koji prikriva šire društveno-ekonomske procese.

\section{NAVEDENA LITERATURA I IZVORI}

Arbenbright, Robert. 1999. "Remaking Moscow. New Places, New Selves". Geographical Review 89/1: 1-22. [http://dx.doi.org/10.2307/216137]

Azaryahu, Maoz. 1986. "Street Names and Political Identity. The Case of East Berlin". Journal of Contemporary History 21/4: 581-604. [http://dx.doi.org/10.1177/002200 948602100405]

Azaryahu, Maoz i Rebbecca Kook. 2002. "Mapping the Nation. Street Names and Arab-Palestinian Identity. Three Case Studies". Nations and Nationalism 8/2: 195-213.

Cohen, Saul B. i Nurit Kliot. "Place-Names in Izrael's Ideological Struggle over the Adminsitered Territories". Annals of the Association of American Geographers 82/4: 653-680. [http://dx.doi.org/10.1111/j.1467-8306.1992.tb01722.x]

Crljenko, Ivana. 2008. "Izraženost identiteta u gradskoj toponimiji kvarnerskih i istarskih gradova”. Hrvatski geografski glasnik 70/1: 67-90.

Čapo, Jasna i Valentina Gulin Zrnić. 2012. “Oprostornjavanje antropološkog diksursa. Od metodološkog problema do epistemološkog zaokreta”. U Mjesto, nemjesto. Interdisciplinarna promišljanja prostora i kulture. Jasna Čapo i Valentina Gulin Zrnić, ur. Zagreb: Institut za etnologiju i folkloristiku, ZRC SAZU, 9-68.

Čolović, Ivan. 2014. Rastanak s identitetom. Beograd: Biblioteka XX vek.

Fehervari, Krisztina. 2002. "American Kitchens, Luxury Bathrooms, and the Search for a 'Normal' Life in Postsocialist Hungary." Ethnos 67/3: 369-400. [http://dx.doi.org/10.1080/0 014184022000031211]

Feldman, David. 2005. "Renaming Cities in Bosnia and Herzegovina". International Journal of Constitutional Law 3/4: 649-662. [http://dx.doi.org/10.1093/icon/moi043]

Grgin, Borislav. 2007. "Primjer selektivnog pamćenja. Hrvatski srednjevjekovni vladari u nazivlju ulica i trgova najvažnijih hrvatskih gradova”. Povijesni prilozi 3: 283-295. 
Gulin Zrnić, Valentina. 2009. Kvartovska spika. Značenja grada i urbani lokalizmi u Novom Zagrebu. Zagreb: Institut za etnologiju i folkloristiku, Jesenski i Turk.

Gulin Zrnić, Valentina. 2012. "Prostor i mjesto u hrvatskoj etnologiji/kulturnoj antropologiji". U Mjesto, nemjesto. Interdisciplinarna promišljanja prostora i kulture. Jasna Čapo i Valentina Gulin Zrnić, ur. Zagreb: Institut za etnologiju i folkloristiku, ZRC SAZU, 69-110.

Jordan, Jennifer. 2006. Structures of Memory. Understanding Urban Change in Berlin and Beyond. Stanford: Stanford University Press.

Jovanović, Nebojša. 2007. "Protiv liberalnog revizionizma”. Reč 75/21: 169-216.

Katzur, Klaus. 1987. Berlins Strassennamen. Berlin: Haude und Spener.

Lefebvre, Henri. 1991. The Production of Space. Oxford, Cambridge: Blackwell Publ.

Letica, Slaven. 2007. Let iznad kukavičjeg gnijezda. Zagreb: Jesenski i Turk.

Light, Duncan. 2004. "Street Names in Bucharest, 1990-1997. Exploring the Modern Historical Geographies of Post-socialist Change”. Journal of Historical Geography 30: 154-172. [http://dx.doi.org/10.1016/S0305-7488(02)00102-0]

Light, Duncan, Ion Nicolae i Bogdan Suditu. 2002. "Toponymy and the Communist City. Street Names in Bucharest, 1948-1965". GeoJournal 56: 135-144. [http://dx.doi.org/ 10.1023/A:1022469601470]

Malešević, Miroslava. 2008. "Nasilje identiteta". U Kulturne paralele. Svakodnevna kultura u socijalističkom periodu. Zorica Divac, ur. Beograd: Etnografski institut SANU, 11-34.

Manojlović Pintar, Olga. 2008. "Uprostoravanje ideologije. Spomenici Drugog svetskog rata i kreiranje kolektivnih identiteta”. U Dijalog povijesničara/istoričara 10/1. Zagreb: Friedrich Neumann Stiftung, 287-307.

Markovina, Dragan. 2014. Između crvenog i crnog. Split i Mostar u kulturi sjećanja. Zagreb, Sarajevo: Plejada, University Press.

Milo, Daniel. 1996. "Street Names". U Realms of Memory. Rethinking the French Past, 2. Pierre Nora i Lawrence Kritzman, ur. New York: Columbia University Press, 362-389.

Mirošević, Lena. 2011. "Imena ulica i trgova kao odraz zajednčkoga kulturno-povijesnog naslijeđa”. Kartografija i geoinformacije 10/16: 57-71.

Palmberger, Monika. 2012. "Renaming of Public Space. A Policy of Exclusion in Bosnia and Herzegovina". MMG Working Paper 12-2: 8-26.

Palonen, Emilia. 2008. "The City-text in Postcommunist Budapest. Street-names, Memorials and Politics of Commemoration". GeoJournal 73: 219-230. [http://dx.doi.org/10.1007/ s10708-008-9204-2]

Potkonjak, Sanja i Tomislav Pletenac. 2007. “Grad i ideologija. 'Kultura zaborava' na primjeru grada Siska”. Etnološka tribina 19/1: 171-198.

Radović, Srđan. 2013. Grad kao tekst. Beograd: Biblioteka XX vek.

Rihtman-Auguštin Dunja. 2000. Ulice moga grada. Beograd: Biblioteka XX vek.

Robinson, Guy M, Stan Engelstoft i Alma Pobric. 2001. "Remaking Sarajevo. Bosnian Nationalism after the Dayton Accord". Political Geography 20: 957-980. [http://dx.doi. org/10.1016/S0962-6298(01)00040-3]

Soja, Edward. 1996. Thirdspace. Journeys to Los Angeles and Other Real-and-Imagined Places. Hoboken: Blackwell Publ.

Stanić, Jelena, Laura Šakaja i Lana Slavuj. 2009. "Preimenovanja zagrebačkih ulica i trgova". Migracijske i etničke teme 25/1-2: 89-124.

Stojanović, Dubravka. 2008. Kaldrma i asfalt. Urbanizacija i evropeizacija Beograda 18901914. Beograd: Udruženje za društvenu istoriju. 
Šakaja, Laura. 2012. "Mjesto u diskursu humane geografije”. U Mjesto, nemjesto. Interdisciplinarna promišljanja prostora i kulture. Jasna Čapo i Valentina Gulin Zrnić, ur. Zagreb: Institut za etnologiju i folkloristiku, ZRC SAZU, 111-128.

Šikanjić, T. i dr. “Omladinska najčešća ulica”. Nezavisne novine, 27. 10. 2007.

Timotijević, Miloš. 2000. “Nazivi ulica Čačka 1893-1992. Jedan vek izgrađivanja kolektivnog identiteta”. Godišnjak za društvenu istoriju 7/2-3: 221-250.

\title{
THE POLITICS OF SYMBOLS IN CITY STREETS: PATTERNS OF RENAMING THE PUBLIC SPACE IN POST-YUGOSLAV COUNTRIES
}

\author{
SUMMARY
}

Street renaming as a symbolic practice of identity politics has been studied in Croatian and other ethnologies/anthropologies in this part of Europe since the 1990s, facilitated by the so-called spatial turn in the social sciences and humanities. Academic interest in these politics of (public) space emerged with the mass renaming of streets, squares, neighbourhoods, even entire towns, which began in the 1990s, when these practices were determined by the overall transformation of the political and economic (the "transition" from socialism to capitalism) and national paradigm (the breakup of Yugoslavia and the establishment of new independent states). Being one of the many modes of novel identity and memory politics, "street spatialization" of ideology was intensively pursued (as in the earlier historical periods), with certain similarities, but also differences when compared to the other former socialist countries in Europe. Having in mind the contents and the scale of these recent interventions in the symbolic public space, one can distinguish three prevailing patterns of street renaming in the post-Yugoslav states (which were characteristic of certain countries and periods, with inevitable exceptions): partial correction of memory of socialism and modification of national narratives, comprehensive erasing of spatial marks on the recent past and substantial remaking of national imagery, and a complete break from the spatial symbolism of the previous epoch primarily serving the newest ethno-political goals. These patterns were implemented in various periods in the last 25 years, and while they might seem very contemporary and characteristic of the Yugoslav successor-states, they usually represent spatial-political practices already implemented in the earlier periods and in other European countries.

Key words: odonyms/hodonyms, politics of space, politics of identity, collective memory, "post-socialist" period 